\title{
Mutagenic potential of Cordia ecalyculata alone and in association with Spirulina maxima for their evaluation as candidate anti-obesity drugs
}

\author{
R.P. Araldi ${ }^{1,2}$, B.M. Rechiutti ${ }^{1}$, T.B. Mendes ${ }^{1,3}$, E.T. Ito ${ }^{1}$ and E.B. Souza ${ }^{1}$ \\ ${ }^{1}$ Laboratório de Biologia Molecular, Genética e Mutagênese, \\ Universidade Estadual Paulista "Júlio de Mesquita Filho", Assis, SP, Brasil \\ ${ }^{2}$ Programa de Pós-Graduação Interunidades em Biotecnologia, \\ Universidade de São Paulo, São Paulo, SP, Brasil \\ ${ }^{3}$ Programa de Pós-Graduação em Biologia Estrutural e Funcional, \\ Universidade Federal de São Paulo, São Paulo, SP, Brasil \\ Corresponding author: E.B. Souza \\ E-mail: edislane@assis.unesp.br
}

Genet. Mol. Res. 13 (3): 5207-5220 (2014)

Received October 28, 2013

Accepted June 4, 2014

Published July 7, 2014

DOI http://dx.doi.org/10.4238/2014.July.7.14

\begin{abstract}
Obesity is one of the most important nutritional disorders, and can be currently considered as an epidemic. Although there are few weight reduction drugs available on the market, some new drug candidates have been proposed, including Cordia ecalyculata, a Brazilian plant with anorectic properties, and Spirulina maxima, a cyanobacterium with antioxidant and anti-genotoxic activity. In this study, we evaluated the mutagenic potential of $C$. ecalyculata at doses of 150,300 , and $500 \mathrm{mg} / \mathrm{kg}$ alone and in association with $S$. maxima at doses of 75,150 , and $250 \mathrm{mg} / \mathrm{kg}$, respectively, through an in vivo micronucleus test, using mice of both sexes, and an in vitro micronucleus test and comet assay, using human peripheral blood. For all tests, cyclophosphamide was used as a positive control. The results showed that treatment of $300 \mathrm{mg} / \mathrm{kg} \mathrm{C}$. ecalyculata and the combination treatment of $500 \mathrm{mg} / \mathrm{kg} \mathrm{C}$. ecalyculata with $250 \mathrm{mg} / \mathrm{kg} S$. maxima
\end{abstract}


resulted in anorectic effects. The mutagenic tests did not reveal any clastogenic or genotoxic activity for any treatment, indicating that these candidates could be marketed as weight-reduction drugs. Moreover, the drugs contain chemo-preventive substances that can protect against tumorigenesis, which has been associated with obesity.

Key words: Cordia ecalyculata; Spirulina maxima; Micronucleus; Comet assay; Mutagenesis

\section{INTRODUCTION}

With increased availability of high-energy foods in combination with a tendency toward more sedentary lifestyles and genetic factors, obesity has emerged as one of the most important nutritional disorders, and can be currently considered an epidemic (Francischi et al., 2000; Flier and Maratos-Flier, 2013). Obesity is a non-transmissible chronic disease that is characterized by excess body fat, and has multifactorial causes (Scarpato et al., 2011; Flier and Maratos-Flier, 2013).

According to the World Health Organization (WHO), in 2011 there were 1.6 billion adults and 20 million children classified as overweight, and 400 million people were classified as obese worldwide. The WHO also estimated that by 2015 , these numbers will likely increase to 2.5 billion overweight and 700 million obese individuals worldwide. In particular, a significant increase in the incidence of obesity has been documented in Brazil in conjunction with a decrease in malnutrition; in $2003,40 \%$ of the Brazilian population was considered to be overweight (Batista-Filho and Rissin, 2003).

This scenario is alarming and constitutes an important public health concern because obesity is associated with metabolic, cardiovascular, respiratory, and hepatobiliary diseases as well as malignancies, including uterine, cervical, breast, ovarian, endometrial, kidney, gastric, esophageal, liver, gallbladder, and pancreatic cancers. Therefore, obesity can generate significant costs to the public health system, contributing to $20 \%$ of malignancies in women and $14 \%$ in men (Francischi et al., 2000; Flier and Maratos-Flier, 2013; Boeing, 2013; Lehnert et al., 2013; Gilbert and Slingerland, 2013; Williams, 2013).

Although pharmacotherapy is indicated for individuals with a body mass index greater than $27 \mathrm{~kg} / \mathrm{m}^{2}$, there are few weight-reducing drugs available on the market (Francischi et al., 2000; Kushner, 2013). The drugs most commonly exploited for appetite suppression have two basic pathways of action: 1) central-acting anorectic drugs (sibutramine), which enhance the neurotransmission of the monoamines norepinephrine, serotonin, and dopamine; and 2) classic adrenergic agents such as benzphetamine, phendimetrazine, diethylpropion, mazindol, and phentermine (Kushner, 2013).

However, these substances lead to a diversity of side effects such as increased anxiety, drowsiness, gastrointestinal disorders, and cardiac arrhythmias (Francischi et al., 2000; Kushner, 2013), indicating an urgent need for the identification of new weight-reducing agents. Indeed, it is estimated that the epidemic control of obesity could prevent approximately 97,000 deaths resulting from obesity-associated cancers in the United States alone (Gilbert and Slingerland, 2013). Among the new candidate drugs that could help in weight reduction are extracts of Cordia ecalyculata and the cyanobacteria Spirulina maxima. 
C. ecalyculata Vell. (synonym C. salicifolia Cham.), popularly known as "porangaba", "buggy tea", or "coffee bush", is a shrub with a height of 8-10 m and a diameter of 30-40 $\mathrm{cm}$ belonging to the family Boraginaceae that is distributed throughout the Brazilian territory, and is also found in the rainforests of Argentina and Paraguay (Menghini et al., 2008; da Silva et al., 2010). Its extract is marketed in Brazil and internationally under the name Pholia magra and has diuretic activity, leading to appetite suppression and weight reduction (Menghini et al., 2008; da Silva et al., 2010).

Previous studies revealed that $C$. ecalyculata extract shows inhibitory effects against herpes simplex virus type I (Hayashi et al., 1990), and has cardiotonic properties (Matsunaga et al., 1997), hypolipidemic effects (Siqueira et al., 2006), and cytotoxicity against certain types of tumor cells (Arisawa, 1994). The plant is characterized by high concentrations of caffeine, potassium, allantoic acid, and allantoin (Menghini et al., 2008).

S. maxima Setchet Gardner is a non heterocystic, filamentous, planktonic, and photosynthetic cyanobacterium (Pandey and Tiwari, 2010) belonging to the order Nostocales, family Oscillatoriaceae, and is characterized by its $65 \%$ protein and $30 \%$ essential amino acids contents, in addition to containing chelated minerals as iron, potassium, and magnesium, as well as vitamins such as biotin, cyanocobalamin, calcium pantothenate, folic acid, inositol, thiamine, alpha-tocopherol, pyridoxine and riboflavin, phenolic acids, and beta-carotene, and fatty acids such as linoleic and gamalinoleic acid (Dalay, 2002).

S. maxima has anti-inflammatory, analgesic, antioxidant, antiviral, cytostatic, lipolytic, hepatoprotective, keratolytic, nutritive, and hypolipidemic activities, and is therefore considered to be one of the greatest discoveries of the 21st century in the field of nutrition (Ponce-Canchihuamán et al., 2010). Furthermore, studies show that the genus Spirulina has anti-carcinogenic and anti-genotoxic properties (Miranda et al., 1998; Mishima et al., 1998; Mittal et al., 1999).

The use of herbal medicine aims to prevent, cure, or minimize disease and its symptoms. However, the transformation from a natural product, such as C. ecalyculata and S. maxima, into a medicinal product should aim at preserving the chemistry and pharmacological integrity while ensuring the maintenance of its biological action and safety for consumption. Thus, toxicological genetic tests are essential to guarantee the safety of drug candidates before they can enter the international market to ensure that they do not confer a risk of carcinogenesis (Witte et al., 2007).

Among the available genetic toxicological tests, the micronucleus test (MNT) and the comet assay are considered to be gold-standard cytogenetic methods (Flores and Yamaguchi, 2008). The MNT was developed by Schmid et al. (1975) and was first used in erythrocytes obtained from the bone marrow of mice (Ribeiro et al., 2003). This test is widely accepted by international agencies and government institutions as part of a battery test for the assessment of new chemicals or drug candidates prior to entering the market (Ribeiro et al., 2003). Therefore, the MNT constitutes a major noninvasive cytogenetic technique that can detect chromosomal mutations, which are the key mechanism leading to carcinogenic events (Fenech, 2000; Carbonari et al., 2005).

However, the experience gained over several decades of toxicology studies reveals that one test is not sufficient to detect all types of mutagenic effects (Witte et al., 2007). Furthermore, a negative result obtained by a test conducted to investigate chromosomal damage in rodent hematopoietic cells is not sufficient to conclude that the component is not mutagenic to somatic cells. Therefore, based on the correlations between results obtained in rodents and humans, the US Food and Drug Administration (FDA) recommended additional testing, both in vitro and in vivo (Witte et al., 2007). 
The comet assay, also known as single cell gel electrophoresis, was introduced by Östling and Johanson in 1984 and later modified by Singh et al. (1988), and possesses the advantages of being a simple and versatile technique that requires only a small number of cells and can be performed with any eukaryotic cell population (Godschalk et al., 2013). In addition, the technique has a wide spectrum of DNA damage detection, and can therefore serve as an integrator test and a complementary assay to other tests (Godschalk et al., 2013).

Thus, in the present study, we aimed to evaluate the anorectic action and the clastogenic and genotoxic potential of C. ecalyculata at three commonly marketed doses $(150,300$, and $500 \mathrm{mg} / \mathrm{kg}$ ). We further evaluated these effects when C. ecalyculata was combined with S. maxima at respective doses of $75 \mathrm{mg} / \mathrm{kg}(\mathrm{Ce} 150+\mathrm{Sm} 75), 150 \mathrm{mg} / \mathrm{kg}(\mathrm{Ce} 300+\mathrm{Sm} \mathrm{150})$, and $250 \mathrm{mg} / \mathrm{kg}$ (Ce $500+\mathrm{Sm} 250)$. An in vivo MNT was conducted in polychromatic erythrocytes of mice and two in vitro tests were conducted (an MNT and a comet assay) in human binucleated lymphocytes.

\section{MATERIAL AND METHODS}

\section{In vivo MNT in polychromatic erythrocytes and anorectic evaluation}

We used a total of 80 mice (Mus musculus, albino, Swiss strain), 40 males and 40 females aged between 7 and 11 weeks, obtained from the central biotery of Universidade Estadual Paulista "Júlio de Mesquita Filho" (UNESP). The protocols used were approved by the Ethics Committee on Animal Use of the same university (protocol No. 001194/10). The choice of mice was based on the fact that oncogenetic and functional studies have shown that they do not lose or sequester micronucleated erythrocytes, such as occurs in rats (Ribeiro et al., 2003; Griffiths et al., 2005).

The mice were acclimated in the biotery of UNESP - Faculdade de Ciências e Letras de Assis - for five days under the following conditions: 12:12-h light/dark cycle, 150 lux lighting, temperature of $22^{\circ} \pm 2^{\circ} \mathrm{C}$, water and food ad libitum. The mice were divided into eight groups of five animals each, separated by sex (Table 1). The analysis of anorectic action was conducted by measuring body weight before and after mice received treatments.

\begin{tabular}{|c|c|c|c|c|}
\hline Group & Treatment & $\begin{array}{l}\text { In vivo } \mathrm{MNT} \\
\text { Dose }(\mathrm{mg} / \mathrm{kg})\end{array}$ & $\begin{array}{l}\text { In vitro } \mathrm{MNT} \\
\text { Dose }(\mu \mathrm{L} / \mathrm{mL})\end{array}$ & $\begin{array}{l}\text { Comet assay } \\
\text { Dose }(\mu \mathrm{L} / \mathrm{mL})\end{array}$ \\
\hline$\overline{\mathrm{C}+}$ & Cyclophosphamide & 50 & 50 & 50 \\
\hline $\mathrm{C}-$ & Saline & - & Not applied & Not applied \\
\hline Ce 150 & C. ecalyculata & 150 & 150 & 150 \\
\hline Ce 300 & C. ecalyculata & 300 & 300 & 300 \\
\hline Ce 500 & C. ecalyculata & 500 & 500 & 500 \\
\hline Ce $150+\operatorname{Sm} 75$ & C. ecalyculata $+S$. maxima & $150+75$ & Not tested & $150+75$ \\
\hline $\mathrm{Ce} 300+\mathrm{Sm} 150$ & C. ecalyculata $+S$. maxima & $300+150$ & Not tested & $300+150$ \\
\hline Ce $500+\operatorname{Sm} 250$ & C. ecalyculata + S. maxima & $500+250$ & Not tested & $500+250$ \\
\hline
\end{tabular}

The positive control groups $(\mathrm{C}+)$ of both sexes were treated with $50 \mathrm{mg} / \mathrm{kg}$ cyclophosphamide (Sigma-Aldrich; St. Louis, MO, USA) by intraperitoneal injection, administered in a single dose. The negative control groups (C-) of both sexes were treated with $0.3 \mathrm{~mL}$ saline by 
gavage, performed twice a day for seven consecutive days. The experimental groups received a final volume of $0.3 \mathrm{~mL}$ respective treatment solution (Table 1) through gavage, performed twice a day for seven consecutive days. The mice were sacrificed by cervical dislocation 48 $\mathrm{h}$ after the final dose administration. The femurs were removed and the bone marrow was extracted by injecting $1 \mathrm{~mL}$ fetal bovine serum (Cultilab; Campinas, SP, Brazil). The material was homogenized on a Petri dish and centrifuged for $5 \mathrm{~min}$ at $36.54 \mathrm{~g}$. The pellet was collected and smeared onto $26 \times 76-\mathrm{mm}$ slides. The material was fixed in absolute methanol for $5 \mathrm{~min}$ and subjected to the following staining protocol: $10 \mathrm{~min}$ in 100\% Giemsa (eosin methylene blue), washed in distilled water, placed in a solution of 1:5 Giemsa:phosphate buffer, $\mathrm{pH}$ 6.0, for $8 \mathrm{~min}$, and washed in xylene. The slides were mounted by gluing a coverslip with Entellan. The material was analyzed under a binocular optical microscope at a total magnification of 1000X. A total of 2000 polychromatic erythrocytes were analyzed per animal, and the frequency of micronucleated polychromatic erythrocytes (MNPCEs) per animal was calculated.

The statistical analyses were performed using the Biostat software version 5.0. The Student $t$-test and the nonparametric Wilcoxon test were used to verify the effectiveness of the drug on weight loss (i.e., change in weight before and after the different treatments), and analysis of variance (ANOVA) was used for comparisons among the treatment groups. The evaluation of the frequency of MNPCEs was performed using the chi-square test, as recommended by Ribeiro et al. (2003). All statistical tests were interpreted at a significance level of 5\%.

\section{In vitro MNT in binucleated lymphocytes}

Five milliliters peripheral blood was collected from 10 volunteers $(5$ men and 5 women), using a heparinized vacutainer system. The subjects were aged 18-25 years and did not use drugs or any kind of chemical substance, including alcohol and tobacco. The material collected was used in the in vitro MNT and comet assay. The protocols were approved by the Ethics Committee in Research of UNESP - Faculdade de Ciências e Letras de Assis (process No. 1679/2010).

The material was immediately processed in order to avoid possible damage to the DNA. For each individual, five cultures were mounted and distributed into five treatment groups, as shown in Table 1. The combination of C. ecalyculata and S. maxima at three different doses was performed as a complementary test to evaluate the clastogenic action of the extract of C. ecalyculata since previous studies demonstrated the anti-clastogenic action of $S$. maxima (Miranda et al., 1998; Mishima et al., 1998; Mittal et al., 1999). Thus, the combination was not tested in the in vitro MNT but rather through the comet assay, which has high DNA damage detection sensitivity.

The cultures were performed by addition of $0.2 \mathrm{~mL}$ peripheral blood in a culture flask containing $5 \mathrm{~mL}$ RPMI 1640 medium, 15\% fetal bovine serum, $0.1 \mathrm{~mL}$ L-glutamine, and 0.1 $\mathrm{mL}$ phytohemagglutinin. The material was incubated at $37^{\circ} \mathrm{C}$ for $8 \mathrm{~h}$, and then added to 0.1 $\mathrm{mL}$ C. ecalyculata solutions, respectively (Table 1). After $44 \mathrm{~h}, 0.2 \mathrm{~mL}$ cytochalasin B was added to block cytokinesis. After $72 \mathrm{~h}$, the culture was stopped with the addition of $0.5 \mathrm{~mL}$ methanol:acetic acid fixative (3:1) for $5 \mathrm{~min}$ at room temperature. The material was centrifuged at $10.39 \mathrm{~g}$ and the supernatant was discarded. The pellet was homogenized with $5 \mathrm{~mL}$ fixative and centrifuged at $10.39 \mathrm{~g}$. The pellet was aspirated and transferred to slides, which were stained with a 1:3 Giemsa:phosphate buffer solution, $\mathrm{pH} 6.8$, for $8 \mathrm{~min}$. 
After staining, coverslips were placed on slides with Entellan ${ }^{\circledR}$ and the material was analyzed in a blind test under a binocular optical microscope to observe the frequency of micronucleated binucleated lymphocytes in a total of 1000 analyzed cells. Statistical analysis was performed using the Kruskal-Wallis test followed by a post-hoc Dunn test, both at a significance level of $5 \%$.

\section{Comet assay}

Slides for the comet assay were prepared as follows: slides of 26 x $76 \mathrm{~mm}$ were embedded in a solution of normal melting point agarose (NMA; Invitrogen; Carlsbad, CA, USA) diluted in phosphate-buffered solution (PBS) to $1.5 \%$ at $60^{\circ} \mathrm{C}$, and one side of each slide was wiped clean with a paper towel. The slides were dried in a horizontal position overnight.

The blood samples were collected and fractionated into aliquots of $200 \mu \mathrm{L}$ each in $0.2-$ $\mathrm{mL}$ polypropylene tubes containing $200 \mu \mathrm{L}$ solution composed of RPMI 1640 medium with different concentrations of the drugs tested (Table 1). One blood aliquot from each donor, not treated with any compound was used as a negative control, and one aliquot treated with $50 \mu \mathrm{L} /$ $\mathrm{mL}$ cyclophosphamide was used as a positive control. Aliquots were incubated at $37^{\circ} \mathrm{C}$ for 1 $\mathrm{h}$ under constant agitation.

After incubation, the aliquots were centrifuged for $1 \mathrm{~min}$ at $504 \mathrm{~g}$, and the supernatant was discarded. Ten microliters obtained pellet was added to $75 \mu \mathrm{L}$ low melting point agarose, and a final volume of $85 \mu \mathrm{L}$ was immediately transferred to NMA pre-coated slides. The slides were covered with coverslips and maintained at $4^{\circ} \mathrm{C}$ for $20 \mathrm{~min}$. The coverslips were gently removed and the slides were placed in a coplin jar containing lysis solution $[2.5 \mathrm{mM} \mathrm{NaCl}$, $100 \mathrm{mM}$ ethylenediaminetetraacetic acid (EDTA), $10 \mathrm{mM}$ Tris-HCl, $1.1 \%$ Triton $\mathrm{X}-100$, and $11.2 \%$ dimethyl sulfoxide] at $4^{\circ} \mathrm{C}$ for $1 \mathrm{~h}$. Subsequently, all procedures were conducted under dark conditions to prevent the induction of DNA damage.

After lysis, the slides were washed with PBS and transferred to an electrophoresis tank containing electrophoresis buffer $(300 \mathrm{mM} \mathrm{NaOH}$ and $1 \mathrm{mM}$ EDTA, $\mathrm{pH}>13)$ at $4^{\circ} \mathrm{C}$ for $40 \mathrm{~min}$ to induce unwinding of double-stranded DNA. Next, the electrophoretic run was performed with a current of $25 \mathrm{~V}(0.86 \mathrm{~V} / \mathrm{cm}), 300 \mathrm{~mA}$ for $20 \mathrm{~min}$ to promote the migration of free DNA fragments toward the anode. The slides were transferred to a coplin jar containing neutralizing buffer (400 mM Tris-HCl, $\mathrm{pH} 7.5$ ) for $5 \mathrm{~min}$. The material was fixed in absolute ethanol for $5 \mathrm{~min}$.

The slides were stained with $75 \mu \mathrm{L} 20 \mu \mathrm{g} / \mathrm{mL}$ ethidium bromide solution, and analyzed under an epifluorescence microscope (Carl Zeiss Axio Scope A1) equipped with an excitation filter of 510-560 nm and barrier of $590 \mathrm{~nm}$, at a total magnification of 400X. One hundred nucleoids were analyzed per slide, which were scored on a scale of 0 (without DNA damage) to 3 (maximum DNA damage), according to Tug et al. (2011). The scores were obtained by summing the product of the observed number of nucleoids per class by its respective class value. Statistical analysis was performed using the Kruskal-Wallis test followed by the post-hoc Dunn test, both with a significance level of 5\%.

\section{RESULTS}

\section{Analysis of the anorectic action}

The mice were weighed before and after the treatments and the results are shown in 
Table 2. The Shapiro-Wilk test revealed that the samples were normally distributed $(\mathrm{P}>0.05)$, except for the combination treatment group Ce $500+\operatorname{Sm} 250$ of females $(\mathrm{P}=0.0183$ and $\mathrm{P}=$ 0.0464 before and after treatment, respectively). Based on these data, we performed the Student $t$-test for paired samples that were normally distributed and the nonparametric Wilcoxon test for the group of females that did not show normality, both at a significance level of $5 \%$. The results indicated significant differences in weight for groups $\mathrm{C}$ - and $\mathrm{Ce} 500+\mathrm{Sm} 250$ of males and C+, C-, Ce 150, Ce 500, Ce 150 + Sm 75, and Ce $300+$ Sm 150 of females (Table 3). In both sexes, there was an increase in weight for the negative control groups (C-), as expected. An increase in weight was observed in the positive control group $(\mathrm{C}+)$ of female mice.

Table 2. Body weight before and after the different treatments, of ten mice, being five male and five female, followed by the values of mean and stand deviation (SD).

\begin{tabular}{|c|c|c|c|c|c|c|c|c|c|c|c|c|c|c|c|c|}
\hline \multirow[b]{2}{*}{ Male } & \multicolumn{2}{|c|}{$\mathrm{C}+$} & \multicolumn{2}{|c|}{ C- } & \multicolumn{2}{|c|}{ Ce 150} & \multicolumn{2}{|c|}{ Ce 300} & \multicolumn{2}{|c|}{ Ce 500} & \multicolumn{2}{|c|}{ Ce $150+\operatorname{Sm} 75$} & \multicolumn{2}{|c|}{ Ce $300+\operatorname{Sm} 250$} & \multicolumn{2}{|c|}{$\mathrm{Ce} 500+\operatorname{Sm} 250$} \\
\hline & Before & After & Before & After & Before & After & Before & After & Before & After & Before & After & Before & After & Before & After \\
\hline 1 & 24.2 & 23.7 & 2 & 32.1 & 27.2 & 25.1 & 27.8 & 27.6 & 29.0 & 29.5 & 34.5 & 35.9 & 40.2 & 39.4 & 39.9 & 38.9 \\
\hline 2 & 27.7 & 27.8 & 32.7 & 38.6 & 27.6 & 28.2 & 31.0 & 35.3 & 33.1 & 32.9 & 35.7 & 34.7 & 43.8 & 43.8 & 43.0 & 42.9 \\
\hline 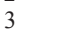 & 29.0 & 30.5 & 35.7 & 44.6 & 30.3 & 33.1 & 36.2 & 35.8 & 36.9 & 33.3 & 35.8 & 37.7 & 44.3 & 46.0 & 47.1 & 46.0 \\
\hline 4 & 29.8 & 32.4 & 37.5 & 44.8 & 33.0 & 38.8 & 36.2 & 36.6 & 40.9 & 42.7 & 37.3 & 37.7 & 48.0 & 49.9 & 47.7 & 46.4 \\
\hline$J$ & 30.1 & 35.6 & 38.2 & 45.1 & 36.8 & 39.9 & 33.1 & 37.8 & 44.0 & 46.0 & 40.3 & 40.7 & 48.9 & 52.9 & 55.3 & 54.7 \\
\hline Means & 28.1 & 30.0 & 34.5 & 41.0 & 30.9 & 33.0 & 32.8 & 34.6 & 36.7 & 36.8 & 36.7 & 37.3 & 45.0 & 46.4 & 46.6 & 45.7 \\
\hline SD & 2.4 & 4.5 & 3.8 & 5.6 & 4.0 & 6.4 & 3.5 & 4.0 & 5.9 & 7.0 & 2.2 & 2.2 & 3.5 & 5.2 & 5.8 & 5.8 \\
\hline Female & Before & After & Before & After & Before & After & Before & After & Before & After & Before & After & Before & After & Before & $\overline{\text { After }}$ \\
\hline 1 & 1.8 & 22.7 & . & 26.8 & 20.1 & 21.7 & 23.2 & 22.7 & (51. & 29.7 & 51.0 & 28.0 & 36.2 & 35.2 & (J & 35. \\
\hline 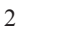 & 24.3 & 24.6 & 23.4 & 27.4 & 28.6 & 24.9 & 26.8 & 26.8 & 34.3 & 30.2 & 35.5 & 31.9 & 37.9 & 37.8 & 38 & 36.0 \\
\hline 2 & 27.9 & 34.6 & 25.7 & 30.5 & 29.0 & 25.2 & 29.5 & 28.7 & 36.7 & 33.6 & 38.6 & 37.3 & 40.6 & 39.3 & 39.2 & 39.6 \\
\hline 4 & & 38.3 & 25.8 & 30.8 & 29.3 & 26.8 & 31.1 & 31.4 & 37 & 35.2 & & 39 & 41.9 & 41.2 & 39 & 40.0 \\
\hline 5 & & 40.5 & & 31.1 & 32.1 & 27.8 & & 32.9 & & 39.1 & & 39.7 & 42.5 & 41.6 & 56.9 & 57.3 \\
\hline Mea & 28.4 & 32.1 & 25.8 & 29.3 & 29.1 & 25.2 & 28.9 & 28.5 & 36.0 & 33.5 & 37.0 & 35.1 & 39.8 & 39.0 & 41.9 & 41.6 \\
\hline SD & 5.8 & 8.0 & 3.0 & 2.0 & 1.9 & 2.3 & 4.2 & 4.0 & 3.1 & 3.8 & 3.3 & 5.0 & 2.6 & 2.6 & 8.5 & 9.0 \\
\hline
\end{tabular}

\begin{tabular}{|c|c|c|c|c|}
\hline \multirow[t]{2}{*}{ Treatments } & \multicolumn{2}{|c|}{ Male } & \multicolumn{2}{|c|}{ Female } \\
\hline & Statistic values & $\mathrm{P}$ & Statistic values & $\mathrm{P}$ \\
\hline $\mathrm{C}+$ & -1.7312 & 0.0792 & -2.7500 & 0.0256 \\
\hline $\mathrm{C}-$ & -6.9757 & 0.0011 & -4.0307 & 0.0079 \\
\hline Ce 150 & -1.5410 & 0.0991 & 9.4007 & 0.0004 \\
\hline Ce 300 & -1.5602 & 0.0968 & 1.6054 & 0.0918 \\
\hline Ce 500 & -0.0989 & 0.4630 & -4.7847 & 0.0044 \\
\hline Ce $150+\operatorname{Sm} 75$ & -1.2440 & 0.1407 & 2.2637 & 0.0431 \\
\hline Ce $300+\operatorname{Sm} 150$ & -1.6318 & 0.0890 & 4.0000 & 0.0081 \\
\hline Ce $500+\operatorname{Sm} 250$ & 3.8485 & 0.0092 & $t /$ Wilcoxon $=26.0000$ & 0.3770 \\
\hline
\end{tabular}

The experimental groups showed a weight reduction in males treated with the maximum combination dose (Ce $500+\mathrm{Sm} 250)$ and in females treated with $C$. ecalyculata alone at doses of 150 and $500 \mathrm{mg} / \mathrm{kg}$ and in combination with $S$. maxima at doses of $150+75$ and $300+150$ $\mathrm{mg} / \mathrm{kg}$. In order to compare the anorectic action of different treatments, ANOVA was performed followed by the post-hoc Tukey test, revealing significant differences in weight between groups among the male $(\mathrm{F}=4.8723, \mathrm{P}=0.001)$ and female $(\mathrm{F}=14.0667, \mathrm{P}=0.000)$ mice. 
The anorectic effect was similar among the Ce 300, Ce 500, Ce $150+\mathrm{Sm} 75$, Ce 300 $+\mathrm{Sm}$ 150, and Ce $500+\mathrm{Sm} 250$ groups in males, and between the Ce 300 and Ce $500+\mathrm{Sm}$ 250 groups in females (Table 4 ).

\begin{tabular}{|c|c|c|c|c|c|c|c|c|}
\hline Male & $\mathrm{C}+$ & $\mathrm{C}-$ & Ce 150 & $\mathrm{Ce} 300$ & Ce 500 & Ce $150+\operatorname{Sm} 75$ & Ce $300+\operatorname{Sm} 150$ & Ce $500+\operatorname{Sm} 250$ \\
\hline 1 & $-0.5^{\mathrm{a}}$ & $+3.3^{\mathrm{a}}$ & $-2.1^{\mathrm{a}}$ & $-0.2^{\mathrm{ab}}$ & $+0.5^{\mathrm{ab}}$ & $+1.4^{\mathrm{ab}}$ & $-0.8^{\mathrm{ab}}$ & $-1.0^{\mathrm{ab}}$ \\
\hline 2 & $+0.1^{\mathrm{a}}$ & $+5.9^{\mathrm{a}}$ & $+0.6^{\mathrm{a}}$ & $+4.3^{\mathrm{ab}}$ & $-0.2^{\mathrm{ab}}$ & $-1.0^{\mathrm{ab}}$ & $0.0^{\mathrm{ab}}$ & $-0.1^{\mathrm{ab}}$ \\
\hline 3 & $+1.5^{\mathrm{a}}$ & $+8.9^{\mathrm{a}}$ & $+2.8^{\mathrm{a}}$ & $-0.4^{\mathrm{ab}}$ & $-3.6^{\mathrm{ab}}$ & $+1.9^{\mathrm{ab}}$ & $+1.7^{\mathrm{ab}}$ & $-1.1^{\mathrm{ab}}$ \\
\hline 4 & $+2.6^{\mathrm{a}}$ & $+7.3^{\mathrm{a}}$ & $+5.8^{\mathrm{a}}$ & $+0.4^{\mathrm{ab}}$ & $+1.8^{\mathrm{ab}}$ & $+0.4^{\mathrm{ab}}$ & $+1.9^{\mathrm{ab}}$ & $-1.3^{\mathrm{ab}}$ \\
\hline 5 & $+5.5^{\mathrm{a}}$ & $+6.9^{\mathrm{a}}$ & $+3.7^{\mathrm{a}}$ & $+4.7^{\mathrm{ab}}$ & $+2.0^{\mathrm{ab}}$ & $+0.4^{\mathrm{ab}}$ & $+4.0^{\mathrm{ab}}$ & $-0.6^{\mathrm{ab}}$ \\
\hline Female & $\mathrm{C}+$ & $\mathrm{C}-$ & Ce 150 & $\mathrm{Ce} 300$ & Ce 500 & Ce $150+\operatorname{Sm} 75$ & Ce $300+$ Sm 150 & $\mathrm{Ce} 500+\operatorname{Sm} 250$ \\
\hline 1 & $+0.9^{\mathrm{a}}$ & $+3.5^{\mathrm{a}}$ & $-5.0^{\mathrm{b}}$ & $-0.5^{\mathrm{bc}}$ & $-2.0^{\mathrm{b}}$ & $-3.8^{\mathrm{b}}$ & $-1.0^{\mathrm{b}}$ & $-0.6^{\mathrm{bc}}$ \\
\hline 2 & $+0.3^{\mathrm{a}}$ & $+4.0^{\mathrm{a}}$ & $-3.7^{b}$ & $0.0^{\mathrm{bc}}$ & $-4.2^{\mathrm{b}}$ & $-3.6^{\mathrm{b}}$ & $-0.1^{\mathrm{b}}$ & $-2.4^{\mathrm{bc}}$ \\
\hline 3 & $+6.7^{\mathrm{a}}$ & $+4.8^{\mathrm{a}}$ & $-3.8^{\mathrm{b}}$ & $-0.8^{\mathrm{bc}}$ & $-3.1^{\mathrm{b}}$ & $-1.3^{\mathrm{b}}$ & $-1.3^{b}$ & $+0.4^{\mathrm{bc}}$ \\
\hline 4 & $+6.5^{\mathrm{a}}$ & $+5.0^{\mathrm{a}}$ & $-2.5^{\mathrm{b}}$ & $+0.3^{\mathrm{bc}}$ & $-2.3^{b}$ & $+0.2^{\mathrm{b}}$ & $-0.7^{\mathrm{b}}$ & $+0.6^{\mathrm{bc}}$ \\
\hline 5 & $+4.2^{\mathrm{a}}$ & $+0.2^{\mathrm{a}}$ & $-4.3^{b}$ & $-1.4^{\mathrm{bc}}$ & $-1.0^{\mathrm{b}}$ & $-0.6^{\mathrm{b}}$ & $-0.9^{b}$ & $+0.4^{\mathrm{bc}}$ \\
\hline
\end{tabular}

Numbers followed by at least one equal letter indicate absence of significative statistic differences.

\section{In vivo and in vitro $\mathrm{MNT}$}

The chi-squared test results showed that the number of micronucleated cells in vivo significantly increased in the positive control groups of both sexes, as expected. There was no significant difference in the number of micronucleated cells between the negative control and experimental groups, thus confirming that the drugs, at the tested doses, did not show any aneuploidogenic and/or clastogenic activity in vivo (Table 5).

Table 5. Number of micronucleated polychromatic erythrocytes observed per animal of both sexes, followed by total.

\begin{tabular}{|c|c|c|c|c|c|c|c|c|c|}
\hline \multirow[b]{2}{*}{ Treatments } & \multicolumn{9}{|c|}{ Groups of male mice } \\
\hline & 1 & 2 & 3 & 4 & 5 & Total & $\mathrm{E}$ & $\chi^{2}$ & $\mathrm{P}$ \\
\hline $\mathrm{C}+$ & 7 & 6 & 17 & 7 & 3 & 40 & 8.0 & 14.000 & 0.007 \\
\hline $\mathrm{C}-$ & 4 & 3 & 3 & 0 & 1 & 11 & 2.2 & 4.909 & 0.296 \\
\hline Ce 150 & 3 & 1 & 2 & 3 & 3 & 12 & 2.4 & 1.333 & 0.855 \\
\hline Ce 300 & 3 & 3 & 3 & 3 & 1 & 13 & 2.6 & 1.269 & 0.870 \\
\hline Ce 500 & 0 & 1 & 1 & 2 & 0 & 4 & 0.8 & 3.500 & 0.477 \\
\hline $\mathrm{Ce} 150+\mathrm{Sm} 75$ & 0 & 2 & 0 & 2 & 3 & 7 & 1.4 & 5.142 & 0.272 \\
\hline $\mathrm{Ce} 300+\mathrm{Sm} 150$ & 1 & 3 & 4 & 0 & 0 & 8 & 1.6 & 8.250 & 0.082 \\
\hline \multirow[t]{2}{*}{ Ce $500+\operatorname{Sm} 250$} & 0 & 3 & 2 & 1 & 1 & 7 & 1.4 & 3.714 & 0.446 \\
\hline & \multicolumn{9}{|c|}{ Groups of female mice } \\
\hline Treatments & 1 & 2 & 3 & 4 & 5 & Total & $\mathrm{E}$ & $\chi^{2}$ & $\mathrm{P}$ \\
\hline $\mathrm{C}+$ & 21 & 6 & 13 & 12 & 8 & 60 & 12.0 & 11.166 & 0.024 \\
\hline $\mathrm{C}-$ & 0 & 0 & 2 & 1 & 0 & 3 & 0.6 & 5.333 & 0.254 \\
\hline Ce 150 & 3 & 3 & 3 & 3 & 3 & 14 & 2.8 & 0.285 & 0.990 \\
\hline Ce 300 & 2 & 4 & 1 & 0 & 2 & 9 & 1.8 & 4.888 & 0.290 \\
\hline Ce 500 & 1 & 0 & 0 & 2 & 2 & 5 & 1.0 & 4.000 & 0.406 \\
\hline $\mathrm{Ce} 150+\operatorname{Sm} 75$ & 0 & 2 & 2 & 1 & 2 & 7 & 1.4 & 2.285 & 0.683 \\
\hline Ce $300+\operatorname{Sm} 150$ & 4 & 1 & 2 & 2 & 4 & 13 & 2.6 & 2.769 & 0.597 \\
\hline Ce $500+\operatorname{Sm} 250$ & 0 & 0 & 5 & 2 & 2 & 9 & 1.8 & 9.330 & 0.053 \\
\hline
\end{tabular}

No. of micronucleated cells analysed and expected value (E), Chi-square $\left(\chi^{2}\right)$ and probability (P). 
The Kruskal-Wallis test, followed by the post-hoc Dunn test, revealed that the frequency of micronucleated cells in vitro (among 1000 binucleated lymphocytes) differed significantly between the positive and negative control groups, although no differences were observed between the experimental groups and the negative control $(\mathrm{H}=25.9712, \mathrm{P}=0.0000)$, confirming the in vivo MNT results (Table 6). Together, these results demonstrate that $C$. ecalyculata does not have clastogenic activity.

\begin{tabular}{|c|c|c|c|c|c|}
\hline Sample & $\mathrm{C}+$ & C- & Ce 150 & $\mathrm{Ce} 300$ & $\mathrm{Ce} 500$ \\
\hline 1 & $17^{\mathrm{a}}$ & $8^{\mathrm{b}}$ & $11^{\mathrm{b}}$ & $8^{b}$ & $7^{\mathrm{b}}$ \\
\hline 2 & $16^{\mathrm{a}}$ & $7^{\mathrm{b}}$ & $1^{\mathrm{b}}$ & $1^{\mathrm{b}}$ & $1^{\mathrm{b}}$ \\
\hline 3 & $11^{\mathrm{a}}$ & $4^{\mathrm{b}}$ & $5^{\mathrm{b}}$ & $1^{\mathrm{b}}$ & $0^{\mathrm{b}}$ \\
\hline 4 & $24^{\mathrm{a}}$ & $9^{\mathrm{b}}$ & $1^{\mathrm{b}}$ & $6^{\mathrm{b}}$ & $1^{\mathrm{b}}$ \\
\hline 5 & $12^{\mathrm{a}}$ & $3^{\mathrm{b}}$ & $2^{b}$ & $0^{\mathrm{b}}$ & $3^{b}$ \\
\hline 6 & $12^{\mathrm{a}}$ & $1^{\mathrm{b}}$ & $3^{b}$ & $2^{b}$ & $0^{\mathrm{b}}$ \\
\hline 7 & $13^{\mathrm{a}}$ & $2^{\mathrm{b}}$ & $1^{b}$ & $1^{\mathrm{b}}$ & $0^{\mathrm{b}}$ \\
\hline 8 & $21^{\mathrm{a}}$ & $4^{b}$ & $5^{b}$ & $17^{b}$ & $2^{\mathrm{b}}$ \\
\hline 9 & $18^{\mathrm{a}}$ & $3^{\mathrm{b}}$ & $6^{\mathrm{b}}$ & $11^{\mathrm{b}}$ & $2^{\mathrm{b}}$ \\
\hline 10 & $17^{\mathrm{a}}$ & $1^{\mathrm{b}}$ & $2^{\mathrm{b}}$ & $4^{b}$ & $1^{\mathrm{b}}$ \\
\hline Total & 161 & 42 & 37 & 51 & 17 \\
\hline
\end{tabular}

Number followed by at least one equal letter indicate absence of significative statistic differences.

\section{Comet assay}

A total of 100 nucleoids per treatment were analyzed and given a score of 0 to 3 , according to Tug et al. (2011), and the comet score values are shown in Figure 1. The results of the Kruskal-Wallis test, followed by the post-hoc Dunn test, revealed that scores differed significantly between the positive and negative control groups, but not among experimental groups, and between experimental groups and the negative control $(\mathrm{H}=32.7984 ; \mathrm{P}=0.0000)$ (Table 7). These results confirm the data obtained through the in vivo and in vitro MNTs, and further validate that the drugs, in the tested doses and in their respective associations, are safe from a mutagenic perspective while still demonstrating anorectic properties. Together, the results show that these drugs are potential candidates to enter into the global market for obesity treatment.

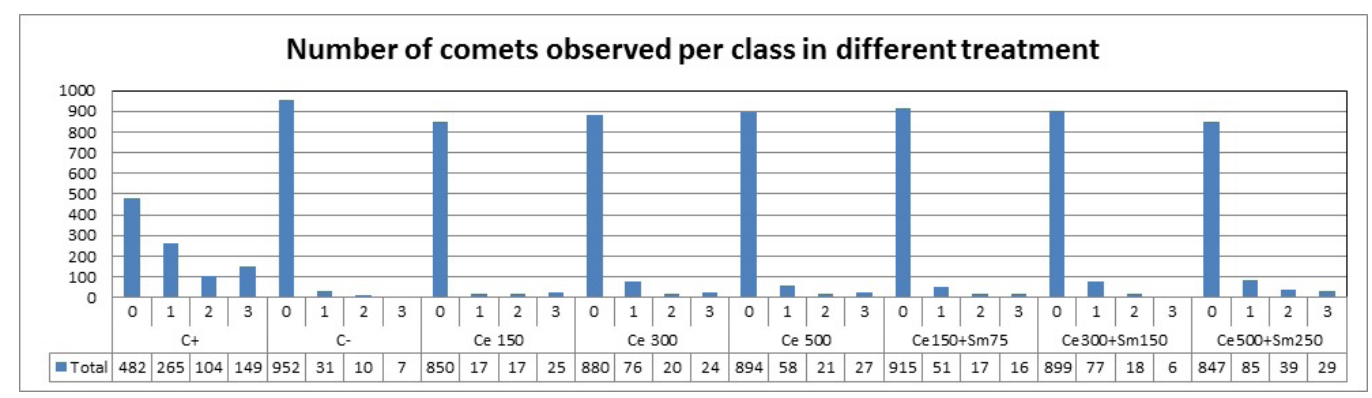

Figure 1. Histogram showing the total number of comets observed per class in different treatments. 
Table 7. Comet score observed per treatment and statistic compasison through Dunn test.

\begin{tabular}{|c|c|c|c|c|c|c|c|c|}
\hline Sample & $\mathrm{C}+$ & C- & Ce 150 & Ce 300 & Ce 500 & Ce $150+\operatorname{Sm} 75$ & Ce $300+$ Sm 150 & Ce $500+\operatorname{Sm} 250$ \\
\hline 1 & $99^{\mathrm{a}}$ & $5^{\mathrm{b}}$ & $14^{\mathrm{b}}$ & $12^{\mathrm{b}}$ & $51^{\mathrm{b}}$ & $20^{\mathrm{b}}$ & $15^{\mathrm{b}}$ & $54^{\mathrm{b}}$ \\
\hline 2 & $52^{\mathrm{a}}$ & $11^{\mathrm{b}}$ & $25^{\mathrm{b}}$ & $15^{\mathrm{b}}$ & $49^{b}$ & $6^{\mathrm{b}}$ & $18^{\mathrm{b}}$ & $36^{\mathrm{b}}$ \\
\hline 3 & $91^{\mathrm{a}}$ & $4^{b}$ & $4^{b}$ & $23^{\mathrm{b}}$ & $5^{\mathrm{b}}$ & $5^{\mathrm{b}}$ & $6^{\mathrm{b}}$ & $29^{b}$ \\
\hline 4 & $99^{\mathrm{a}}$ & $6^{\mathrm{b}}$ & $18^{\mathrm{b}}$ & $31^{\mathrm{b}}$ & $21^{\mathrm{b}}$ & $3^{\mathrm{b}}$ & $5^{\mathrm{b}}$ & $4^{b}$ \\
\hline 5 & $82^{\mathrm{a}}$ & $7^{\mathrm{b}}$ & $3^{\mathrm{b}}$ & $25^{\mathrm{b}}$ & $10^{\mathrm{b}}$ & $3^{\mathrm{b}}$ & $5^{\mathrm{b}}$ & $10^{\mathrm{b}}$ \\
\hline 6 & $43^{\mathrm{a}}$ & $25^{\mathrm{b}}$ & $97^{\mathrm{b}}$ & $60^{\mathrm{b}}$ & $8^{\mathrm{b}}$ & $33^{\mathrm{b}}$ & $30^{\mathrm{b}}$ & $18^{\mathrm{b}}$ \\
\hline 7 & $137^{\mathrm{a}}$ & $4^{b}$ & $11^{\mathrm{b}}$ & $9^{b}$ & $6^{\mathrm{b}}$ & $6^{\mathrm{b}}$ & $6^{\mathrm{b}}$ & $27^{\mathrm{b}}$ \\
\hline 8 & $103^{\mathrm{a}}$ & $6^{\mathrm{b}}$ & $20^{\mathrm{b}}$ & $3^{\mathrm{b}}$ & $3^{b}$ & $5^{\mathrm{b}}$ & $14^{\mathrm{b}}$ & $31^{\mathrm{b}}$ \\
\hline 9 & $104^{\mathrm{a}}$ & $4^{b}$ & $21^{\mathrm{b}}$ & $6^{\mathrm{b}}$ & $7^{\mathrm{b}}$ & $37^{\mathrm{b}}$ & $20^{\mathrm{b}}$ & $6^{\mathrm{b}}$ \\
\hline 10 & $110^{\mathrm{a}}$ & $3^{b}$ & $25^{\mathrm{b}}$ & $5^{\mathrm{b}}$ & $20^{\mathrm{b}}$ & $15^{\mathrm{b}}$ & $12^{\mathrm{b}}$ & $32^{\mathrm{b}}$ \\
\hline
\end{tabular}

Figure 2 shows images of micronucleated cells and class 3 comets from the respective positive controls and normal cells (i.e., without DNA damage), observed in the experimental groups.

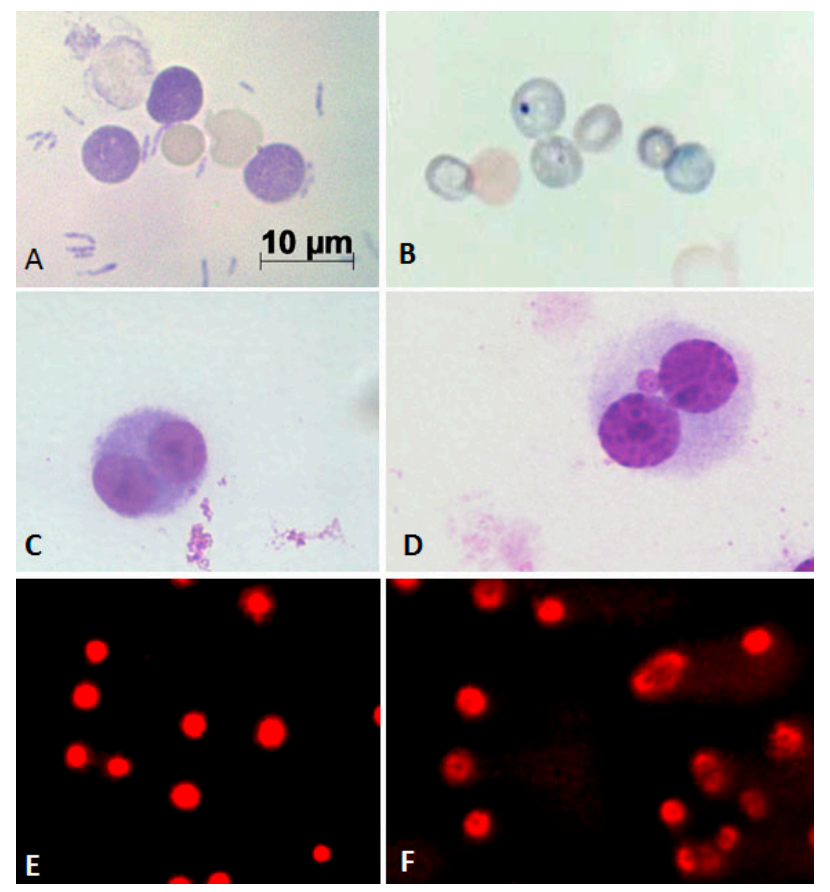

Figure 2. Images of normal polychromatic erythrocytes (A) and micronucleated cell (B), normal binucleated lymphocytes $(\mathbf{C})$ and micronucleated cell $(\mathbf{D})$ and comets class $0(\mathbf{E})$ and $3(\mathbf{F})$.

\section{DISCUSSION}

The increased prevalence of obesity has led to a reduction in the quality of life for a large proportion of the global population, with clear impacts on public health costs; indeed, over $20 \%$ of the USA healthcare costs is spent on obesity-associated complications and deaths. 
Therefore, the search for new treatments that could assist in weight reduction while not conferring additional health risks is necessary (Scarpato et al., 2011; Boeing, 2013; Lehnert et al., 2013; Gilbert and Slingerland, 2013).

In this regard, the evaluation of DNA damage is an essential part of the characterization of new drug candidates before entrance into the global market (Frieauff et al., 2013), making genetic toxicology assessment an important tool in drug evaluations (Dertinger et al., 2011). Among the different mutagenic tests available, the MNT and comet assay have been widely adopted to assess the aneuploidogenic, clastogenic, and genotoxic action of drug candidates owing to their high sensitivity and low costs and execution times when compared to classical cytogenetic methods, which require metaphase observations (Dertinger et al., 2011; Frieauff et al., 2013).

The number of cells analyzed varies according to the technique employed. According to Ribeiro et al. (2003) and Frieauff et al. (2013), for the MNT in polychromatic erythrocytes, analysis of 2000 cells is recommended, whereas for the MNT in binucleated lymphocytes, 1000 cells are recommended for analysis. In the comet assay, only 100 cells need to be analyzed because of the high sensitivity of this assay in detecting free DNA fragments (Araldi et al., 2013). These values for cells analyzed are based on statistical considerations.

Micronuclei are chromosomal fragments or whole chromosomes that are lost during cell division, which can be detected as extra-chromosomal particles (Frieauff et al., 2013), indicating chromosome breakage (clastogenicity), which can lead to genomic instability, an indicator of oncogenic processes (Fenech, 2000; Araldi et al., 2013).

The evaluation of the anorectic ability of the extract of C. ecalyculata and its association with $S$. maxima showed a weight reduction in the male mice for the combination group Ce $500+\mathrm{Sm} 250$ and in females for the treatment groups Ce 150, Ce 500, Ce $150+\mathrm{Sm} \mathrm{75}$, and $\mathrm{Ce} 300+\mathrm{Sm} \mathrm{150}$. However, the ANOVA results revealed a statistically significant anorectic effect only for the female groups of Ce 300 and Ce $500+\mathrm{Sm} 250$, as shown in Table 4, indicating that treatment with C. ecalyculata alone at a dose of $300 \mathrm{mg} / \mathrm{kg}$ and in combination with $S$. maxima at the respective doses of 500 and $250 \mathrm{mg} / \mathrm{kg}$ can both contribute to higher weight reduction.

These results differ from those observed by da Silva et al. (2010), who did not observe an anorectic effect of C. ecalyculata at doses of 500, 1000, and $2000 \mathrm{mg} / \mathrm{kg}$. The difference in the anorectic effect observed between the sexes is likely related to differences in the hormonal environment, which leads to alteration of gene expression and physiological responses to drugs (Guidalini and Tufik, 2007), thereby justifying the need for in vivo testing separately between the sexes.

The results of anorectic action in females are particularly relevant as obesity appears to be more prevalent in women (Flier and Maratos-Flier, 2013). Although obesity presents a nonMendelian pattern of inheritance and there are at least 10 loci associated with obesity, only 3\% of cases are due to a genetic component, indicating that consumption of high-energy foods and sedentary habits are the main risk factors for obesity. Therefore, the search for drugs with different targets has been actively undertaken for the treatment of appetite suppression (Kushner, 2013). The association of C. ecalyculata extract and $S$. maximum is an excellent candidate in this regard, because these drugs have two action pathways: 1) anorectic central action, facilitating binding to adenosine receptors, thereby promoting an extension of adrenaline (C. ecalyculata); and 2) peripheral action due the high protein concentrationfound in S. maxima. 
The evaluation of the mutagenic potential of the treatments through the MNT, both in vivo and in vitro, and the comet assay revealed that they are safe, as they do not show clastogenicity. The tests were conducted in both mouse and human cells, as recommended by the FDA, thus providing confidence in our results. Similar results were observed by da Silva et al. (2010) at doses of 500, 1000, and $2000 \mathrm{mg} / \mathrm{kg}$, who did not observe any genotoxic effects in cells from the peripheral blood of mice, as determined through a comet assay.

Although there are reports showing cytotoxic effects of other Cordia species due to the presence of pyrrolizidine alkaloids, C. ecalyculata does not have cytotoxic activity as it lacks this alkaloid (Rapisarda et al., 1993). Moreover, Caparroz-Assef et al. (2005) and da Silva et al. (2010) showed that C. ecalyculata does not cause toxicity under chronic use.

Gas chromatography, mass spectrometry, and magnetic resonance imaging analyses have shown that $C$. ecalyculata is distinguished by the presence of palmitic, myristic, stearic, oleic, linoleic acid, and high concentrations of spathulenol, a substance that inhibits the growth of Helicobacter pylori strain DSMZ 4867 found in human gastric samples (Menghini et al., 2008). Furthermore, C. ecalyculata is rich in tannins and anthocyanins, which have antioxidant properties, can modulate the expression of adipokines and prevent fat accumulation and insulin resistance type II, a problem frequently observed in obesity (Volp et al., 2008).

S. maximum is distinguished by the presence of alpha-tocopherol, which inhibits nuclear transcription factor kappa B (NF-kB). When activated by cytokines such as tumor necrosis factor- $\alpha$ and interleukin (IL)- 6 and IL-8, NF-kB binds to the regulatory sequence of genes related to the immune processes, apoptosis, cell plasticity, and development, and is therefore related to tumorigenesis (Gilbert and Slingerland, 2013).

Cytokines secreted by preadipocytes attract monocytes and induce high concentrations of leptin, which is responsible for the conversion of monocytes to macrophages that contribute to the further production of cytokines and angiogenic factors, thereby creating a toxic microenvironment in the adipose tissue of obese individuals that is favorable for tumorigenesis (Gilbert and Slingerland, 2013). Given this scenario, the combined treatment of C. ecalyculata and S. maxima at a dose of 500 and $250 \mathrm{mg} / \mathrm{kg}$, respectively, is recommended, as this treatment could achieve an anorectic effect while exerting antitumorigenic activity due to the presence of tannins and alpha-tocopherol.

In summary, the combined treatment of C. ecalyculata and S. maxima at a dose of $500+250 \mathrm{mg} / \mathrm{kg}$ proved to be a promising candidate for weight reduction therapy, and did not exhibit mutagenic action in either mouse or human cells while simultaneously conferring anti-carcinogenic action. This effect, coupled with the absence of adverse effects commonly observed in other similar treatments with drugs such as sibutramine, shows great potential of these new candidates in reducing the incidence of obesity in combination with lifestyle changes such as nutritional education and practical exercises.

\section{ACKNOWLEDGMENTS}

The authors thank the Fundação de Amparo à Pesquisa do Estado de São Paulo (Process \#2010/05649-7) for financial support and the late Dr. Tania Maria Araújo Domingues Zucchi for academic support. 


\section{REFERENCES}

Araldi RP, Melo TC, Diniz N, Mazzuchelli-de-Souza J, et al. (2013). Bovine papillomavirus clastogenic effect analyzed in comet assay. Biomed. Res. Int. 2013: 630683.

Arisawa M, Arisawa M, Fujita A, Hayashi T, et al. (1994). Cell growth inhibition of KB cells by plant extracts. Nat. Med. 48: 338-347.

Batista-Filho M and Rissin A (2003). A transição nutricional no Brasil: tendências regionais e temporais. Cad. Saúde Pública 19: 181-191.

Boeing H (2013). Obesity and cancer-the update 2013. Best. Pract. Res. Clin. Endocrinol. Metab. 27: 219-227.

Caparroz-Assef SM, Grespan R, Batista RCF and Bersani-Amado FA (2005). Toxicity studies of Cordia salicifolia extract. Acta Sci. Health Sci. 27: 41-44.

Carbonari K, Gonçalves L, Roth D and Moreira P (2005). Increased micronucleated cell frequency related to exposure to radiation emitted by computer cathode ray tube video display monitors. Genet. Mol. Biol. 28: 469-474.

da Silva CJ, Bastos JK and Takahashi CS (2010). Evaluation of the genotoxic and cytotoxic effects of crude extracts of Cordia ecalyculata and Echinodorus grandiflorus. J. Ethnopharmacol. 127: 445-450.

Dalay MCEU (2002). Arthrospira maxima [=Spirulina maxima (Stiz.) Geitl., 1930] Aci Lake Strain. J. Fish. Aquat. Sci. 19: 241-245.

Dertinger SD, Torous DK, Hayashi M and MacGregor JT (2011). Flow cytometric scoring of micronucleated erythrocytes: an efficient platform for assessing in vivo cytogenetic damage. Mutagenesis 26: 139-145.

Fenech M (2000). The in vitro micronucleus technique. Mutat. Res. 455: 81-95.

Flier JS and Maratos-Flier E (2013). Biologia da Obesidade. In: Harrison Principios Medicina Interna. 18th edn. (Longo DL, Kasper DL, Jamenson JL, Fauci AS, et al., eds.). Editora Artmed, Porto Alegre, 622-629.

Flores M and Yamaguchi UM (2008). Teste do Micronúcleo: uma triagem para a avaliação genotóxica. Saúde Pesq. 1: 337-340.

Francischi RPP, Pereira LO, Freitas CS and Klopfer M (2000). Obesidade: atualização sobre sua etiologia, morbidade e tratamento. Rev. Nutr. 13: 17-28.

Frieauff W, Martus HJ, Suter W and Elhajouji A (2013). Automatic analysis of the micronucleus test in primary human lymphocytes using image analysis. Mutagenesis 28: 15-23.

Gilbert CA and Slingerland JM (2013). Cytokines, obesity, and cancer: new insights on mechanisms linking obesity to cancer risk and progression. Annu. Rev. Med. 64: 45-57.

Godschalk RW, Ersson C, Riso P, Porrini M, et al. (2013). DNA-repair measurements by use of the modified comet assay: an inter-laboratory comparison within the European Comet Assay Validation Group (ECVAG). Mutat. Res. 757: 60-67.

Griffiths AJF, Wessler SR, Lewontin RC and Gelbart WM (2005). Um Breve Guia dos Organismos Modelo. Introdução à Genética. $8^{\text {a }}$ ed. Editora Guanabara Koogan, Rio de Janeiro, 690-691.

Guindalini C and Tufik S (2007). Uso de microarrays na busca de perfis de expressão gênica-aplicação no estudo de fenótipos complexos. Rev. Bras. Psiquiatr. 29: 370-374.

Hayashi K, Hayashi T, Morita N and Niwayama S (1990). Antiviral activity of an extract of Cordia salicifolia on herpes simplex virus type 1. Planta Med. 56: 439-443.

Kushner RF (2013). Avaliação e Tratamento da Obesidade. In: Harrison Principios Medicina Interna. 18th edn. (Longo DL, Kasper DL, Jamenson JL, Fauci AS, et al., eds.). Editora Artmed, Porto Alegre, 629-636.

Lehnert T, Sonntag D, Konnopka A, Riedel-Heller S, et al. (2013). Economic costs of overweight and obesity. Best. Pract. Res. Clin. Endocrinol. Metab. 27: 105-115.

Matsunaga K, Sasaki S and Ohizume Y (1997). Excitatory and inhibitory effects of Paraguayan medicinal plants Equisetum giganteum, Acanthpspermum australe, Allophylus edlisand, Cordia salicifolia on contraction of rabbit aorta and guinea-pig left atrium. Nat. Med. 51: 478-481.

Menghini L, Epifano F, Leporini L, Pagiotti R, et al. (2008). Phytochemical investigation on leaf extract of Cordia salicifolia Cham. J. Med. Food 11: 193-194.

Miranda MS, Cintra RG, Barros SB and Mancini FJ (1998). Antioxidant activity of the microalga Spirulina maxima. Braz. J. Med. Biol. Res. 31: 1075-1079.

Mishima T, Murata J, Toyoshima M, Fujii H, et al. (1998). Inhibition of tumor invasion and metastasis by calcium spirulan (Ca-SP), a novel sulfated polysaccharide derived from a blue-green alga, Spirulina platensis. Clin. Exp. Metastasis 16: $541-550$

Mittal A, Kumar PV, Banerjee S, Rao AR, et al. (1999). Modulatory potential of Spirulina fusiforms on carcinogen metabolizing enzymes in Swiss albino mice. Phytother Res. 13: 111-114.

Ostling O and Johanson KJ (1984). Microelectrophoretic study of radiation-induced DNA damages in individual mammalian cells. Biochem. Biophys. Res. Commun. 123: 291-298. 
Pandey JP and Tiwari A (2010). Optimization of biomass production of Spirulina maxima. J. Algal Biomass Util. 1: 20-32. Ponce-Canchihuamán JC, Peréz-Mendez O, Hernández-Muñoz R, Torres-Durán PV, et al. (2010). Protective effects of Spirulina maxima on hyperlipidemia and oxidative-stress induced by lead acetate in the liver and kidney. Lipids Health Dis. 9: 35.

Rapisarda A, Ragusa S and De Pasquale A (1993). Hepatotoxic effect of the leaves of some Cordia species. Acta Hort. 332: $237-242$.

Ribeiro LR, Salvadori DMF and Marques EK (2003). Teste do Micronúcleo em Células Humanas in vitro. Mutagênese Ambiental. Editora Ullbra, Canoas, 355.

Scarpato R, Verola C, Fabiani B, Bianchi V, et al. (2011). Nuclear damage in peripheral lymphocytes of obese and overweight Italian children as evaluated by the gamma-H2AX focus assay and micronucleus test. FASEB J. 25: 685-693.

Schmid W (1975). The micronucleus test. Mutat. Res. 31: 9-15.

Singh NP, McCoy MT, Tice RR and Schneider EL (1988). A simple technique for quantitation of low levels of DNA damage in individual cells. Exp. Cell Res. 175: 184-191.

Siqueira VLD, Garcia Cortez DA, de Oliveira CE and Nakamura CV (2006). Pharmacological studies of Cordia salicifolia Cham in normal and diabetic rats. Braz. Arch. Biol. Technol. 49: 215-218.

Tug N, Sandal S, Ozelgun B and Yilmaz B (2011). Correlation of spermiogram profiles with DNA damage in sperm cells of infertile men: a comet assay study. Gynecol. Endocrinol. 27: 49-54.

Volp ACP, Renhe IRT, Barra K and Stringuetta PC (2008). Flavanóides antocianinas: características e propriedades na nutrição e saúde. Rev. Bras. Nutr. Clin. 23: 141-149.

Williams SC (2013). Link between obesity and cancer. Proc. Natl. Acad. Sci. U. S. A. 110: 8753-8754.

Witte I, Plappert U, de WH and Hartmann A (2007). Genetic toxicity assessment: employing the best science for human safety evaluation part III: the comet assay as an alternative to in vitro clastogenicity tests for early drug candidate selection. Toxicol. Sci. 97: 21-26.

World Health Organization (WHO) (2011). Obesity and Overweight. 2011. Obesity and Overweight - Fact Sheet \#311. Available at [http://www.who.int/mediacentre/factsheets/fs311/en/]. Accessed 20 September 2013. 